ISSN 1991-8690

website: http://jsci.utq.edu.iq

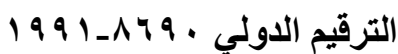

Email: utjsci@utq.edu.iq

\title{
The antigenicity of Staphylococcus aureus in rats
}

\author{
Alaa J. Hassan \\ Shakir H. AL-Alwany \\ *Rahim ,T.Abbas \\ Zahra'a M. A.A \\ Sada Sadiq A.O \\ Rafal Ahmed Lelo \\ Department of biology -College of science -University of Babylon \\ * Babylon Health Office
}

\begin{abstract}
Staphylococcus aureus was isolated from patients of Hilla hospital for surgery .The killed antigen of $S$. aureus was prepared and mixed with incomplete Freund's adjuvant then injected in rats. The results revealed that the effect of $S$. aureus antigen in cellular immunity which including ; phagocytosis ,endocytic killing by neutrophils and ingestion of bacteria by phagocytes at different times of incubation in rats primed with bacterial antigen . The means of Phagocytosis were reached 15.2 ، 35.4 and 50.7 after 10 ,30 and 50 min of incubation respectively 'while the means of endocytic killing were reached 4.8 ، 4.9 'and 9.8 at the same times mentioned above. Furthere more 'the rates of ingestion were 0.48 , 0.178 and 0.196 at the same times respectively'while lower in above tests in control rats . The concentrations of total protein salbumin and crude globulins were appeared lower in treated rats compared with control animals 'which reached $9.45,8.02$ and $1.45 \mathrm{~g} / \mathrm{L}$, while it was $12.34,10.44$ and $1.9 \mathrm{~g} / \mathrm{L}$ for control group respectively .These results suggests that the killed antigen of $S$. aureus stimulated the cellular immunity 'while it was suppressive for humoral immunity in rats.
\end{abstract}

Keyword :- Staphylococcus aureus. antigens • phagocytosis .Humoral . Immunity • Rats 


\section{Introduction:-}

Staphylococcus aureus is a gram positive bacterium that has remained a persistent pathogen (Vancey ،1999) for diverse spectrum of human and animal diseases (Garloni and Zanetti 2005 ). The pathogenicity of this bacteria is mainly due to the production of a number of secreted and cell surface- associated proteins (Mullarky et al., 2001) 'furthermore 'this pathogen regarded as storage for toxin rexoenzymes adhesions and immune-modulating proteins ( Fournier and Philpotte,2005). The outer cell wall of Staphylococci is composed of exposed peptidoglycan and lipoteichoic acids and a range of other toxic secreted products (Sriskandan and Cohen,1999) and these components induced release of the TNF- $\alpha$,IL-6 and IL-10 in human blood (Wang etal.,2000). The toll-like receptor 2 (TLR2) is a signaling receptor for peptidoglycan from S. aureus and Streptococcus pneumonia (Schmander etal. ، 1999 ; Yushimura et al.,1999) .In addition sthere is some evidence that Staphylococcal virulence was by impeding phagocytosis in the infected hosts (O'Riordan and Lee ،2004 ) .Phagocytosis of microorganisms is a key element in host defense against bacterial infections (Silverstein and Steinberg .,1989). There are two principal mechanisms of phagocytosis ,the first is opsonin- dependent phagocytosis (Wright and Silverstein ,1986 ), while the second is opsonin- independent phagocytosis (Ofek et al ., 1995).Furthermore, phagocytes such as macrophages and dendritic cells must differentiated infections self from non infectious agents and initiate an appropriate inflammatory response (Hoffmann et al.,1999).

Neutrophils are the principle line of defense during the initial stages of Staphylococcal infections ، (Paape et al.,1979 ). Pincus et al., (1976) reported that the individuals with neutropenia are more susceptible to $S$. aureus infections . Defects that alter normal PMN cells function 'such as chronic granulomatus diseases predispose individuals to serious $S$. aureus infections (Lekstrom-Himes and Gallin ‘2000).

Albumin is a $69-\mathrm{KDa}$ plasma protein with a variety of physiological functions including ; maintain the blood pressure 'transport to and from tissues of multiple substances and etc., (Emerson,1989;Peters ,1985). Furthermore 'Iglesia et al . '(1999) reported that albumin is a major serum survival factor through it's ability to inhibit of apoptosis by at least two mechanisms : carriage of lysophatic acid and scavenging of reactive oxygen species .

The increased levels of $\gamma$-globulin in serum related to chronic inflammatory diseases ، including infection 'liver diseases 'autoimmune diseases $\operatorname{IgM}$ in viral disease and early bacterial disease 'while the decreased levels of $\gamma$-globulins in serum related to immunodeficiency (genetic or acquired )(Johnson et al. ،2004)

We chose $S$. aureus a prototypical gram -positive microorganisms and an important cause of life threatening bacterial infections in human therefore "the aim of this study is to investigate the cellular and humoral immune response of killed $S$. aureus antigen in rats .

\section{Materials and Methods :-}

\section{1- Laboratory animals :-}

Twenty mature native rats Rattus rattus which have been brought from Karbala university 'college of science, biology department . Their blood were tested for bacterial infections and it was negative for bacterial pathogens and their respective specific antibodies . Rats were kept through out experimentation periods at libidum conditions of ration and housing (Schneider etal . ،1990). The weight of such animals ranged between 300-350 gm and their ages ranged from 4-6 months . 


\section{2- Bacterial Isolates :-}

The $S$. aureus was isolated from respiratory of patients in Hilla hospital for surgery according to Macfaddin (2000) .The bacteria were cultured over night in nutrient broth to make certain that they will be in a logarithmic growth phase then washing by sterile normal saline $(0.85 \%)$ and diluted to give suspension of a bout $1 \times 10^{7}$ cell/ $\mathrm{ml}$.Cells was counted using neubeur chamber ( Chruchshank et al., 1975).

\section{3- Preparation of $S$. aureus antigen :-}

The antigen of this bacteria was prepared according to the Bradshaw (1996).

\section{4- Immunization protocol of rats :-}

The rats were divided into two groups, ten replicates for each group .The first group was treated with $S$. aureus antigen, while the second group, was treated with sterile normal saline $(0.85 \%)$.

The animals of the first group were injected subcutaneously four doses $(0.8 \mathrm{ml})$ for 2 weeks intervals. These doses which include antigen mixed with incomplete Freund's adjuvant in ratio $1: 1$, then the doses above were divided into four parts $(0.2 \mathrm{ml}$ for each $)$ 'and each of sub doses were injected in the two sides of the neck region and both sides of the groin region (Bradshaw,1996) .

\section{5- Blood samples:-}

The blood samples were collected directly from the immunized and controlled rats by heart puncture, seven days after the last injection. The samples were kept in sterile tubes containing anticoagulant (heparin ) AFM -Dispo and placed in refrigerator at $4^{\circ} \mathrm{C}$ in order to measure the phagocytic activity and the concentrations of total protein aalbumin and crude globulins .

\section{5-1:- Phagocytosis Test :-}

The means of phagocytosis, endocytic killing by neutrophils and rates of ingestion for $S$. aureus by phagocytes were measured .The test was done by mixed blood of immunized and controlled rats with suitable a mount of bacterial isolate,then incubated at $37^{\circ} \mathrm{C}$ for different times (10,30 and 50 minutes) ,after that prepare the slides ,stain and examine under oil immersion microscope .( AL-Barrak ،1997)

\section{5-b:- Blood proteins ‘Albumin, Globulins concentration}

The total protein ,albumin and crude globulin were estimated according to manual procedure of linear chemical procedure (company of Almacen Joaquim.costa ,Montgat ,Barcelona(spain).

\section{6- Calculation :-}

A. The positive percentages for neutrophils

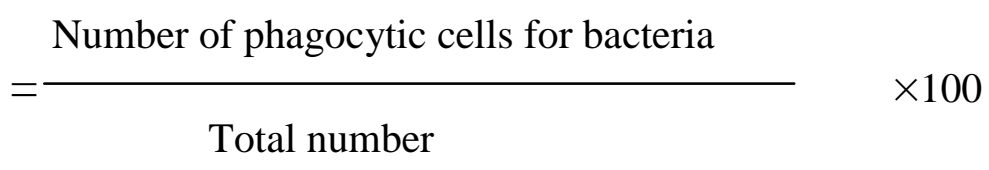

$$
=\frac{\text { OR }}{100 \text { neutrophils }}
$$




\section{B. Endocytic killing $=$ \\ Bacteria (B)/Neutrophils (N)}

Time of incubation

\section{7- Biometry:-}

(AL-Barrak ،1997) (Donald,1989).

\section{RESULTS :-}

Table(1) showed a gradual increase in phagocytosis of $S$. aureus with the time of incubation of the whole blood- bacteria mixtures at times 10,30 and 50 minutes rbut these increase were higher in treated group ( plate 1) compared with control group ( plate 2). In immunized rats the mean of phagocytosis were 15.2 35.4 and 50.7 at time intervals of 10 ,30 and 50 minutes respectively, while it was 25 29.6 and 43.6 in control animals at the same time intervals .

Table (1) :- The means of phagocytosis of $S$. aureus in rats primed with S. aureus antigen at different times of incubation .

\begin{tabular}{|c|c|c|c|c|}
\hline Grouss & number & \multicolumn{3}{|c|}{ phagocytosis mean \pm standard Error } \\
\cline { 3 - 5 } & & $\mathbf{1 0} \mathbf{m i n}$. & $30 \mathrm{~min}$. & $50 \mathrm{~min}$ \\
\hline Treatment & 10 & $\mathbf{1 5 . 2 0 0} \pm \mathbf{1 . 3 3 9}$ & $35.40 \pm 3.419$ & $\mathbf{5 0 . 7 0} \pm 3.249$ \\
\hline control & 10 & $25.00 \pm \mathbf{0 . 9 4 8}$ & $29.60 \pm 1.630$ & $43.60 \pm 1.568$ \\
\hline
\end{tabular}

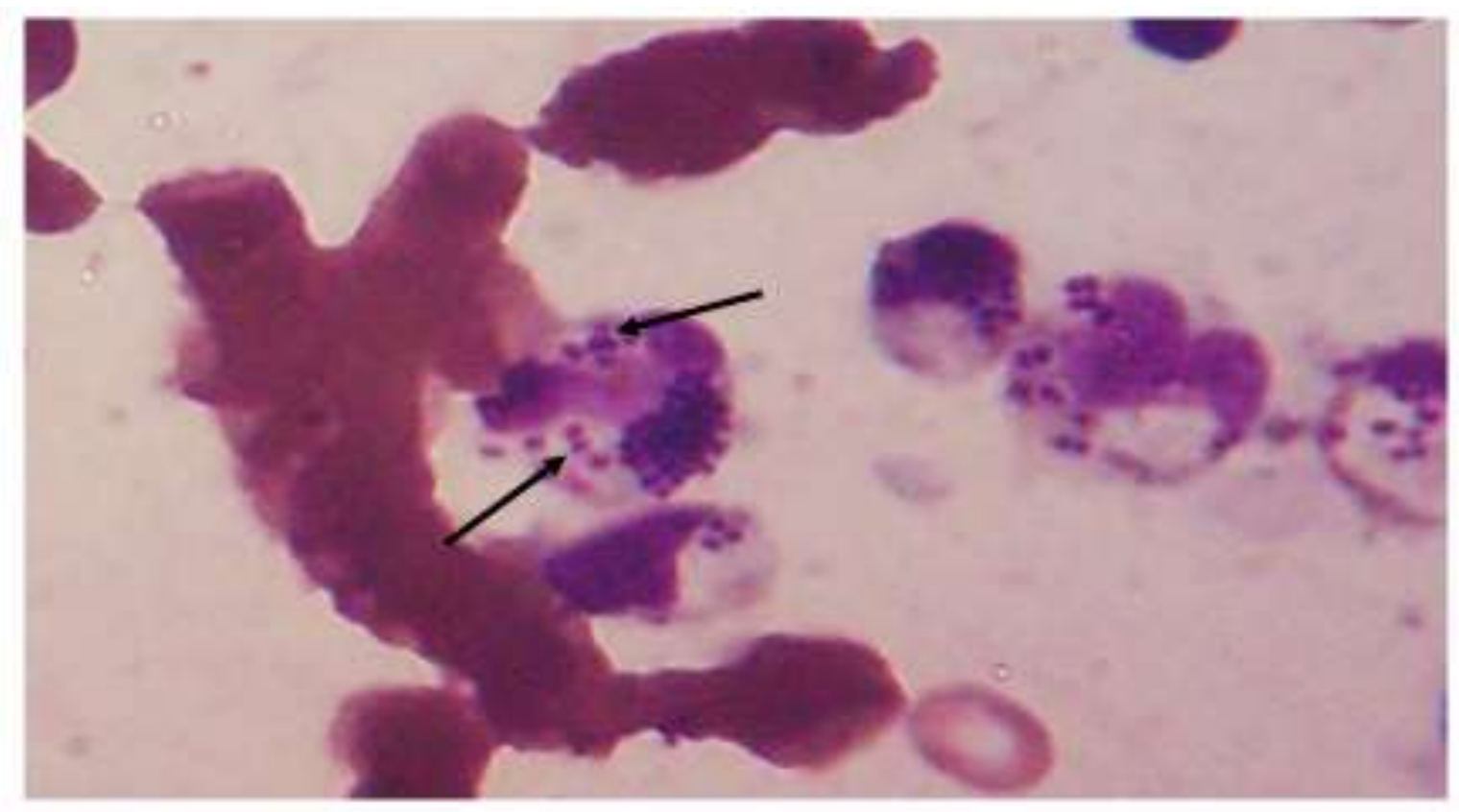

Plate (1): Phagocytosis of $S$. aureus by neutrophils (X100 stained by leishman) 


\section{J.Thi-Qar Sci.}

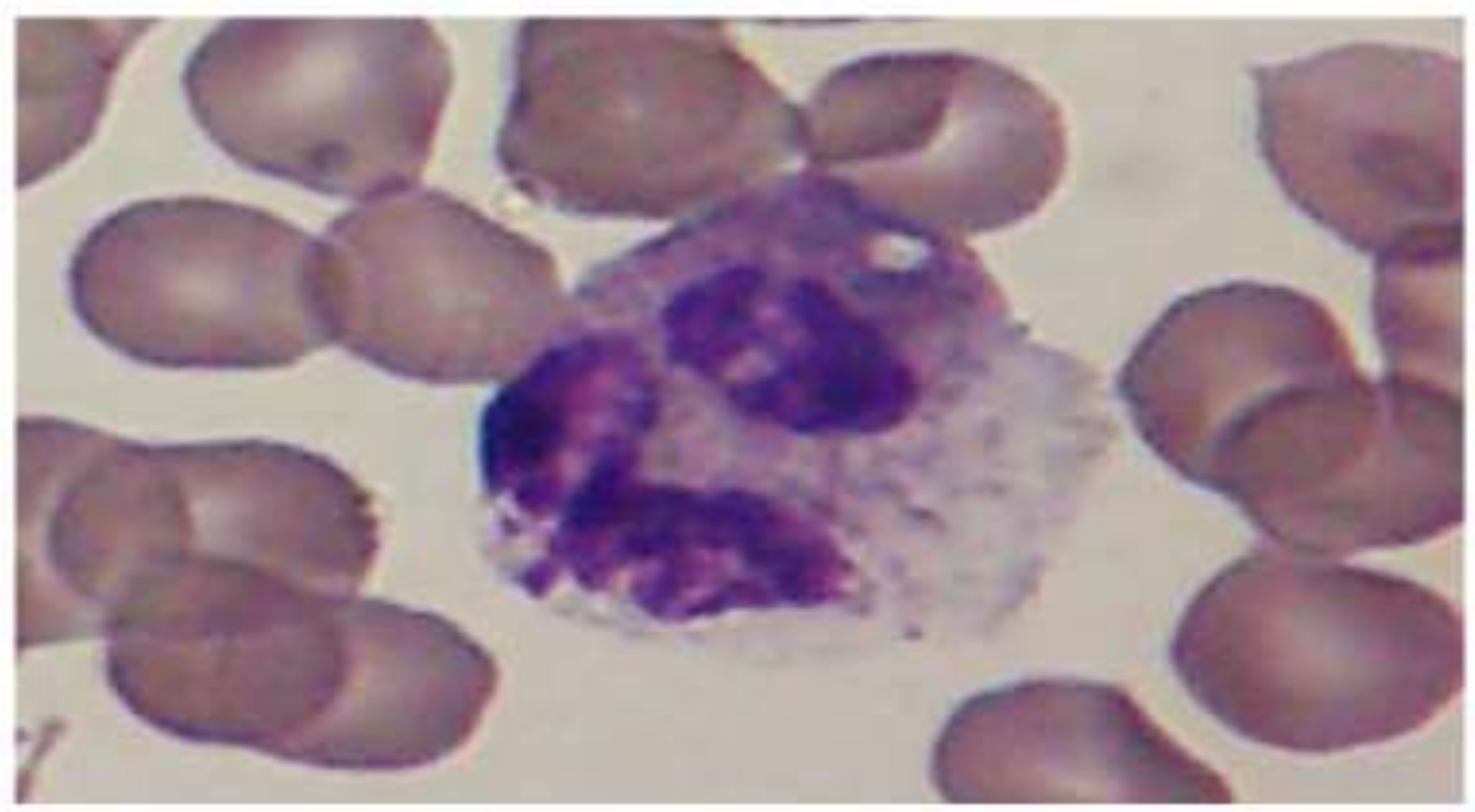

Plate (2): Neutrophil negative (X100 stained by leishman)

The endocytic killing of this bacteria by neutrophils also were increased with the time of incubation and higher in treated group than that in control group. The mean of endocytic killing reached 4.8 ، 4.9 and 9.8 at times mentioned above consuctively in immunized rats ، while it was 3.4 ،4.4 and 4.6 at times 10,30 and 50 minutes respectively ( Table 2).

Table (2):- The endocytic killing of S. aureus by neutrophils in rats primed with $S$. aureus antigen at different times of incubation

\begin{tabular}{|c|c|c|c|c|}
\hline \multirow{2}{*}{ Group } & \multirow{2}{*}{ number } & \multicolumn{3}{|c|}{ B/N mean \pm standard error } \\
\cline { 3 - 5 } & & 10 min. & 30 min. & 50 min. \\
\hline Treatment & 10 & $4.800 \pm 0.61$ & $4.900 \pm 0.566$ & $9.800 \pm 1.404$ \\
\hline control & 10 & $3.400 \pm 0.244$ & $4.400 \pm 0.509$ & $4.60 \pm 0.509$ \\
\hline
\end{tabular}

Meantime ,the rates of ingestion of $S$. aureus by phagocytes, were higher in rats immunized with bacterial antigen in comparison with control group rand reached 0.48 ، 0.178 and 0.196 in treatment at times mentioned above respectively, while it was $0.136 ، 0.150$ and 0.116 in control rats at the same times respectively( Table 3).

Table (3):- The rates of ingestion of $S$. aureus by phagocytes in rats immunized with $S$. aureus antigen at different times of incubation .

\begin{tabular}{|c|c|c|c|c|}
\hline Groups & \multirow{2}{*}{ number } & \multicolumn{3}{|c|}{ Rate of ingestion mean \pm standard Error } \\
\cline { 3 - 5 } & & $10 \mathrm{~min}$. & $30 \mathrm{~min}$. & $50 \mathrm{~min}$. \\
\hline Treatment & 10 & $0.480 \pm 0.061$ & $0.178 \pm 0.022$ & $0.196 \pm 0.028$ \\
\hline control & 10 & $0.136 \pm 0.010$ & $0.150 \pm 0.013$ & $0.116 \pm 0.006$ \\
\hline
\end{tabular}

There were a decreased in mean of concentration of total protein in treated group (9.450 $\mathrm{g} / \mathrm{ml})$ compared with control $(12.340 \mathrm{~g} / \mathrm{L})$ and these results showed a high significance difference between both groups ( Table 4). 


\section{Table (4) :- The concentrations of total proteins $(\mathrm{g} / \mathrm{L})$ in rats primed with} S. aureus antigen

\begin{tabular}{|c|c|c|}
\hline Groups & number & $\begin{array}{c}\text { Total protein }(\mathrm{g} / \mathrm{L}) \\
\text { Mean } \pm \text { standard error }\end{array}$ \\
\hline Treatment & 10 & $9.450 \pm 0.351$ \\
\hline control & 10 & $12.340 \pm 0.282$ \\
\hline
\end{tabular}

Meantime ,the concentrations of albumin in control group were higher than that in treated group also there was a high significance difference $(\mathrm{p}<0.01)$ between two groups of animals (Table 5).

Table (5) :- The concentration of albumin $(\mathrm{g} / \mathrm{L})$ in rats primed with $S$. aureus antigen

\begin{tabular}{|c|c|c|}
\hline Groups & number & $\begin{array}{c}\text { Albumin (g/L) } \\
\text { Mean } \pm \text { standard error }\end{array}$ \\
\hline Treatment & 10 & $8.020 \pm 0.273$ \\
\hline control & 10 & $10.440 \pm 0.112$ \\
\hline
\end{tabular}

Furthermore the mean of concentration of globulins in rats primed with $S$. aureus antigen were lower than that in control group, it was reached 1.450 and $1.900 \mathrm{~g} / \mathrm{L}$ in groups mentioned above respectively (Table 6) .

Table (6) :-The concentrations of globulins $(\mathrm{g} / \mathrm{L})$ in rats primed with $S$. aureus antigen .

\begin{tabular}{|c|c|c|}
\hline Groups & number & $\begin{array}{c}\text { Globulin }(\mathrm{g} / \mathrm{L}) \\
\text { Mean } \pm \text { standard error }\end{array}$ \\
\hline Treatment & 10 & $1.450 \pm 0.118$ \\
\hline control & 10 & $1.900 \pm 0.238$ \\
\hline
\end{tabular}

\section{Discussion :-}

Table 1 '2 and 3 showed significant increases in means of phgocytosis rendocytic killing and rate of ingestion of $S$. aureus in the rats primed with $S$. aureus antigen compared with the control animals. The peptidoglycan and lipoteichoic acids of $S$. aureus induce release of TNF $\alpha$ 'IL- 1B and IL-6 from cultured macrophages - monocytes ( Bhakdi et al . ، 1991). However this bacterium have been shown to activate $\mathrm{T}$ - cell subset (Teisser et al .,1998) as well as provide protection by delay apoptosis in rat neutrophils (Moulding etal .,1999 ) . Silverstein and Steinberg (1989) illustrated that the roles of type I and II class a scavenger receptors (SR-AI/II) in innate immunity to bacterial infections by recognize their cell wall products (lipopolysaccharide and lipoteichoic acids ) 'therefore ,mice deficient SR -AI/IIare more susceptible to intraperitoneal infection with $S$. aureus than control mice .In addition sThomas et al ,.,2000) reported that the opsonin-independent phagocytosis of bacteria is a critical determinant of host survival in bacterial infection . The bacteria or bacterial products stimulate a systemic macrophages in reticulo- endothelial system (RES) and circulating leukocytes (Brandtzaeg et al.,1996). Phagocytes recognition of foreign or 
modified ligands ,such as bacteria and apoptotic cells ,is an essential component of both the innate and adaptive immune responses. Furthermore, particle recognition and internalization is mediated by a variety of phagocytic receptors including the Fc $\gamma \mathrm{R}, \mathrm{CR} 3$, the mannose receptor and members of the surface receptors family (Harvey and Champe , 2008 ) .Sriskandan and Cohen (1999) showed that the Staphylococcal infection induces an influx of neutrophils. Indeed ، $S$. aureus is apyogenic pathogen capable of tissue invasion and evasion of phagocytosis by neutrophils .The innate immune system is capable of recognizing pathogens provides a first line of defense to the host and this system initiates a sequences of events that result in the production and secretion of awide range of inflammatory cytokines and chemokines 'the activation of macrophages/ monocytes , and the initiation of adaptive immunity (Aderem and Ulevitch ,2000;Schnare et al.,2001 ) .The polymorphonuclear leukocytes are important for human innate immunity by killing most invading bacteria ,such as $S$. aureus and these pathogens avoid destruction by PMNs to survive (Voyich et al.,2005) .In addition ,neutrophils are a critical component of innate immunity and are essential for controlling bacterial infections (Lekstrom-Himes and Gallin,2000).

Results have showed a decreases in means of total protein albumin and globulins in primed rats compared with control animals. The inflammatory response initiated by peritoneal inoculation of dilutes $S$. aureus promotes the influx of neutrophils, monocytes and plasma proteins ,such as complement and antibodies (Thomas et al . 2000), furthermore (Johnson et al. ،2004 ) illustrated that the clinical conditions that affect serum protein level :acute inflammation schronic inflammation ,protein loss and redistribution of body fluids .Meantime rpeptidoglycan is a human T-cell mitogen as well as an activator of B-cell because S. aureus contains super antigens (Rasanen and Arvilommi . ،1982). White blood cells can phagocytize kill and degrade the pathogen and the molecules resulting from this degradation are then presented to T-cells to activate adaptive immunity (Aderem and Ulevitch ,2000; Schnare et al., 2001). Thereby 'the adaptive immune system recognize pathogens by antigen receptors that are expressed at the surface of B and T lymphocytes ,these receptors are characterized by specificity and memory (Takeda and Akira, 2003).

The decreased levels of albumin in serum related to acute phase response, liver disease ,increased concentrations of immunoglobulin and genetic an albuminemia 'while the increased level of albumin in serum related to acute dehydration( Johnson et al .,2004).

The significant of this paper lies in the investigation of the humoral and cellular immune response of $S$. aureus in rats that mimics the $S$. aureus infection and their antigenicity in human.

\section{References:}

- Aderem,A. and Ulevitch,R.J.(2000). Toll-like receptors in the induction of the innate immune response. Nature,406:782-787.

- AL-Barrak ,A.Y. (1997). Bacteriological and immunological on Streptococcus group -A isolated from human patient with acute tonsillitis . Athesis of PH.D.degree in microbiology . University of Baghdad .

- Bhakdi ‘S. .; T. Klonisch ; P.Nuber and DW . Fischer.(1991) . Stimulation of monokine production by lipoteichoic acids. Infect .Immun . ‘59:4614 -4620.

- Bradshaw ‘L.T.(1996). Laboratory Immunology $.2^{\text {nd }}$ ed. ‘Saunders College Publishing ,Washington .

- Brandtzaeg ‘P.; L. Osnes ; R. Ovstebo ‘G. B. Jo; A. B. Westvik and P. Kieralf .(1996) . Net inflammatory capacity of human septic shock plasma evaluated by a monocyte - based target 
cell assay :identification of interleakin -10 as a major functional deactivator of human monocytes .J. Exp. Med . ‘184:51-60.

- Cruickshank ‘R.; J.P. Duguid ; B. Marmiom and R.H.H. Smain .(1975). Medical microbiology $.12^{\text {th }}$ ed . 'P.459. The English language book society.

- Donald ‘F.M. (1989). Multivariant statistical method $.2^{\text {nd }}$ ed. ‘University of Pennsylvania ،USA.

- Emerson ،T.E. (1989) . Unique features of albumin : na brief review . Crit. Mem . ،17: 690- 694.

- Fournier ‘B. and Philpott ‘D.J.(2005) Recognition of Staphylococcus aureus by the innate immune system.Clin.Micero.Rev. ،18(3):520-540.

- Garloni ‘M. and M. Zanetti ‘(2005) . CD4 T-cells in tumar immunity . Sponger Semin immunopathology . ،27(1):37-48.

- Harvey, R. A. and Champe , P.C. 2008 . Lippincott's Illustrated Reviews : Immunology.Lippincott Williams and Wilkins. Philadelphia, USA.

- Hoffmann 'J.A. ; F.C. Kafatos ‘C.A. January 'and R.F. Ezekomitz . (1999) . Phylogenetic perspectives in innate immunity. Science $284: 1313-1318$.

- Iglesias ,J.; V. Elizabeth ; Wang ; W. Lieberthal ; J.S. Koh and J.S. Levine (1999) . Albumin is a major serum survival factor for renal tubular cells and macrophages through scavenging of ROS. Am. J . Physiol . 277:711-722.

- Johuson ‘A.M. ‘Ritchie ‘R.F. and Iedue ‘T.B.(2004) ‘Protein learning guide. Adivision of Abbott laboratories.Inc.USA.

- Lekstrom -Himes 'J.A. and J.I . Gallin. (2000) . Immunodeficiency diseases caused by defects in phagocytes .N.Engl. J.Med . ،343: 1703-1714.

- Macfaddin,J.(2002) . Biochemical test for identification of medical bacteria $.3^{\text {rd }}$. 'Amolters Klumer Company ‘Baltimore ‘USA

- Moulding ‘D.A.; C.Walter ; C.A. Hart 'and S.W. Edwards .(1999) .Effects of staphylococcal enterotoxins on human neutrophil functions and apoptosis . Infect . Immun. ،67:2312-2318 .

- Mullarky ‘I.K.C.; N. Frieze; Y.H.Park ‘and L.M. Soordillo .(2001). Staphylococcus aureus agr genotypes with enterotoxin production capabilities can resist neutrophil bactericidal activity. Infect. Immun. 669:45-51.

- Ofek ،I.; J. Golghar ; Y. Keisari and N. Sharon .(1995) . Nouopsonic phagocytosis of microorganisms . Rev .Microbiol . 449:239-276.

- O'Riordan ‘K. and J. Lee . (2004). Staphylococcus aureus capsular polysaccharides Clin .Micro . Rev. ،17 (1) :218-234.

- Paape ‘M.J.; W.P.Wergin ; A.J. Guidry , and R.E. Pearson . (1979). Leukocytes -second line of defense against in vading mastitis pathogen .J.Dairy. Sci. ،26:135-153.

- Peters ‘T.J. 1985. Serum albumin .Adv. protein . Chem . ‘37:161 -245.

- Pincus ‘S.H.; L.A.Boxer ‘and T,P.Stossel.( 1976) . Chronic neutropenia in childhood :analysis of 16 cases and a review of the literature. Am.J.Med . 661:849-861.

- Rasanen ,L. ‘and H .Arvilommi .(1982). Cell walls rpeptedoglycan ‘and lipoteichoic acids of gram- positive bacteria as polyclonal inducers and immuno-modulators of proliferative and lymphokine responses of human and T lymphocytes . Infect Immun. ،35: 523-527.

- Schmander ‘R.; R. Dziarski ‘H. Wesche ,M. Rothe and C.J. Kirschning . (1999). peptidoglycan and lipoteichoic acid - induced cell activation is mediated by toll- like receptor 2 . J,Biol ‘chem. . 274:17406-17409

- Schnare ‘M.;M.Borton ;A.C.Holt ; K. takeda ;S. Akira and R. Medzhitor .(2001) .Toll -like receptors control activation of adaptive immune responses . Nat .Immunol . ، 2:947 -950.

- Schneider ,E. ،Volecker ،6.F. and Hsude ,W.(1990). Age and sex dependence on phospholipids concentration in human erythrocytes. I.H.Med. Lab. Diagn. ،31:86-89

- Silverstein 'S.C. and T.H. Steinberg. (1989). Host defense against bacterial and fungal infections . In Microbiology .B.D. Davis ‘R.Dulbecco ‘H.N.Elsen and H.S.Ginsberg 'editors . J.B. Lippincott company .Philadelphia . 485-505. 
- Sriskandan ,S and Cohen ،J (1999) . Gram-positive sepsis . Mechanisms and differences from gram -negative sepsis . Infect .Dis . Clin .N.Am . 13:397 -412

- Takeda ,K. and Akira S.( 2003). Toll receptors and pathogen resistance .cell. Microbial . 5.143 -153

- Tessier ‘P.A.;P.H. Naccache ; K.R.Diener; R.P.Gladue ‘Neote ; L. Clark -Lemis ،and S.R. McColl . (1998) . Induction of acute inflammation in vivo by staphylococcal super antigens .LL. Critical role for chemokines 'ICAM -I rand TNF $\alpha$.J.Immun . ، 161:1204-1211.

- Thomas ‘C.A.; Y.Li; T.kodama 'H.suzuki; S.C.Silverstein and J. Elkhoury .(2000) . Protection from lethal gram- positive infection by macrophage scavenger receptor- dependent phagocytosis. J.Exp .Med . ،191:147-156 .

- Voyich ‘J.M .; K.R.Braughton ; D.E.Sturdevant ; A.R.Whitney ; B.Salim; S.F. Porcella ; R.D. Long ; D.W. Darward ; D.J. Gardner ; B.N. Kreismirth ; J.M. Musser and F.R.Deleo . (2005) . Insights into mechanisims used by Staphylococcus aureus to avoid destruction by human neutrophils . J. Ammonal . ، 175:3907 -3919.

- Voyich 'J.M.; J.M. Musser and F.R. Deleo .(2004). Staphylococcus pyogens and human neutrophilis :a paradigm for evasion of innate host defense by bacterial pathogens. Microbes .Infect. ،6:1117-123.

- Wang ,J.E.; P.F. Jorgensen ; M. Almlof ;C. Tiedemann ،S.J . Foster ;; A.O . Aasen and R. Solberg . (2000) .Peptidoglycan and lipoteichoic acid from Staphylococcus aureus induce tumor necrosis factor alpha 'Interleukin 6 (IL-6) and IL-10 production in both T-cells and monocytes in a human whole blood model . Infected .Immun . 68 (7) :3695 -3970 .

- Wright 'S.D. and S.C. Silverstein . (1986) . Overview : the function of receptors in phagocytosis .In cellular immunology .D.M. Weir reditor . Blackmell scientific publications Oxford ,London .41.1-41.14.

- Yancey 'R.J.J. (1999) . Vaccines and diagnostic methods for bovine mastitis :fact and fiction . Adv. Vet. Med. ،41:257-273 .

- Yoshimura ,A. ; E. Lien ; R.R. Ingalls ; E. Yuomanen ; R. Dziarski and D. Golenbock .( 1999). Cutting edge : recognition of gram- positive bacterial cell wall components by the innate immune system occurs via toll- like receptore2 . J. Immunol . ،163: 1-5 .

\section{الخلاصة}

تم عزل بكتريا المكورات العنقوديه الذهبيه من مرضى مستشفى الحذه الجر احي • حضر المستضد المقتول

لتلتك البكتريا ومزج هع دساعد فرويند غير الكامل ، ثم حقن في الجرذان البيض.اظهرت النتائج تأثير مستضد

البكترياعلى المناعه الخلويه و التي تضمنت البلعمه ,القتل داخل خلوي بو اسطه العدلات وهضم البكتريا بو اسطه الخلايا

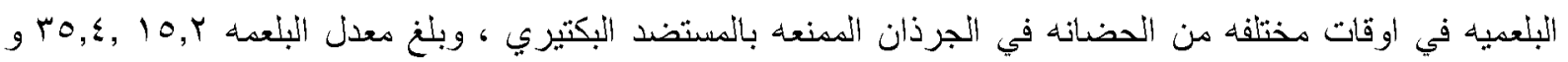

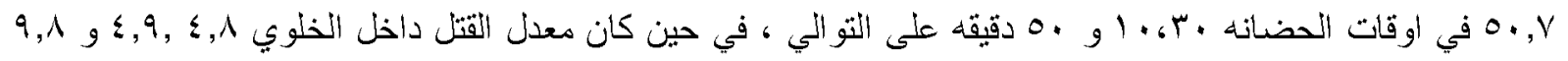

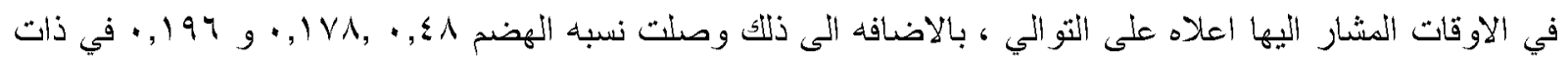

الاوقات على التو الني ، بينما كانت النتائج منخفضه للفحوصات اعلاه في جرذان السيطره ـ اظهرت تر اكيز البروتين

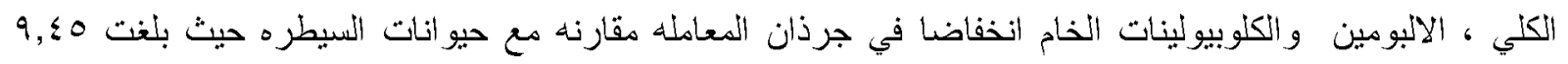

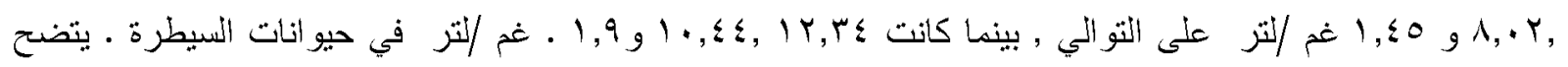
من هذه النتائج ان المستضد المقتول لتنك البكتريا هو محفز للمناعه الخلويه ، في حين انه كان كابحا للمناعه الخلطيه في الجرذان. 